\title{
JACEK WOJNICKI
}

Samorząd lokalny w Polsce i w Europie

Pułtusk 2008, s. 237

\section{MONIKA SZCZEPANKOWSKA}

Akademia Humanistycznej im. Aleksandra Gieysztora w Pułtusku

K

siążka pt. Samorzą lokalny w Polsce i Europie autorstwa Jacka Wojnickiego powstała jako skrypt na podstawie wykładów wygłaszanych w Akademii Humanistycznej w Pułtusku w ramach przedmiotu: samorząd i wspólnoty lokalne. Jest to już trzecie poszerzone i uaktualnione wydanie książki ukazane nakładem Akademii Humanistycznej im. Aleksandra Gieysztora w Pułtusku. Należy zauważyć, iż jak dotąd na rynku wydawniczym ukazało się wiele publikacji dotyczących tej problematyki. Niniejsza publikacja to próba zapoznania w prosty i czytelny sposób z ogólnymi zagadnieniami dotyczącymi funkcjonowania samorządu lokalnego w Polsce i w Europie.

Całość prezentowanej publikacji podzielona została na dziewięć rozdziałów. Przyjęty w nich podział na odrębne zagadnienia sprawia, że układ ten jest przejrzysty i konsekwentny, przez co ułatwia czytelnikowi orientację w poszczególnych wątkach tematycznych. Oprócz tego praca składa się z krótkiego wstępu oraz bibliografii. Brakującą kwestią w tak przyjętej konstrukcji wydaje się brak zakończenia, które stanowiłoby podsumowanie omawianych kwestii. Nie można jednak nie docenić, iż podjęty przez autora wysiłek pozwolił w sposób przejrzysty i logiczny przedstawić poruszaną przez niego problematykę.

W rozdziale pierwszym zatytułowanym „Administracja publiczna” autor wyróżnia dwa rozumienia terminu administracja: statyczne i dynamiczne. W rozumieniu statycznym utożsamia administrację z pewnym określonym podmiotem lub grupą podmiotów, natomiast w rozumieniu dynamicznym traktuje administrację jako szczególnego rodzaju działanie. Następnie termin administracja definiuje w znaczeniu negatywnym oraz 
pozytywnym. Omówione zostały także podstawowe cechy administracji jak również decentralizacja i dekoncentracja władz. Poza tym przedstawiony został dualizm administracji. Rozdział ten to również ukazanie pozycji wojewody jako przedstawiciela rządu w terenie. Jak zauważa autor ze względu na złożoność realizowanych zadań oraz zasięg terytorialny współczesne państwa wyodrębniają trzy rodzaje podziału terytorialnego państwa: podstawowy, pomocniczy oraz specjalny.

Rozdział drugi Geneza i istota samorząu lokalnego poświęcony został omówieniu historii samorządu terytorialnego po 1918 roku w Polsce. Samorząd lokalny stanowi jedną z podstawowych instytucji prawno-ustrojowych państwa współczesnego. Funkcjonowanie samorządu jest normowane w aktach prawa najwyższego rzędu, w tym w konstytucjach. Natomiast sam termin „samorząd” jak formułuje autor oznacza „ustalony prawem zakres kompetencji do zawiadywania własnymi sprawami, samodzielne i niezależne zawiadywanie swoimi sprawami w zakresie administracji państwowej (publicznej), a także samodzielne wykonywanie pewnych funkcji państwowych o charakterze administracyjnym". Autor przywołuje stwierdzenie Zygmunta Niewiadomskiego, który samorząd określa jako „wyodrębniony w strukturze państwa, powstały z mocy prawa, związek lokalnego społeczeństwa powoływany do samodzielnego wykonywania administracji publicznej, wyposażony w materialne środki umożliwiające realizację nałożonych nań zadań”. Z kolei wg Michała Kuleszy „celem działalności władzy lokalnej jest identyfikacja i organizowanie zaspokojenia zbiorowych potrzeb miejscowej ludności". Autor odwołuje się również do Zbigniewa Leońskiego, kiedy wskazuje na wady i niebezpieczeństwa wynikające $\mathrm{z}$ funkcjonowania samorządu lokalnego oraz Eugeniusza Ochendowskiego określając zalety istnienia samorządu. Dalej autor wymienia pięć podstawowych zasad funkcjonowania samorządności lokalnej. Zalicza do nich zasadę: pomocniczości, decentralizacji władzy publicznej, samodzielności, demokracji przedstawicielskiej oraz wolności zrzeszania.

Rozdział trzeci „Organizacja samorządu lokalnego” to przedstawienie władz i ich zadań w gminie, powiecie i województwie. Każda jednostka samorządowa została potraktowana jako oddzielne zagadnienie. Kolejnym zagadnieniem poruszanym w tym rozdziale jest kwestia referendum lokalnego. Należy pamiętać, iż w samorządzie lokalnym władza jest wykonywana w formach demokracji bezpośredniej oraz demokracji przedstawicielskiej. Jak twierdzi autor „podstawą klasycznej instytucji samorządu lokalnego była idea wykonywania administracji państwowej przez społeczność lokalną w formie demokracji przedstawicielskiej. Jed- 
nak rozrost i komplikacja zadań, wzrost liczebności mieszkańców, zmiany w politycznym mechanizmie wykonywania administracji zadecydowała o przewadze form demokracji pośredniej". Podstawę prawną przeprowadzania referendum lokalnego stanowią ustawy: o samorządzie gminnym, o samorządzie powiatowym, o samorządzie województwa oraz ustawa z 15 września 2000 roku o referendum lokalnym. W myśl tych ustaw wyróżniamy dwa rodzaje referendów. Po pierwsze referendum obligatoryjne, które przeprowadza się w przypadku samoopodatkowania się mieszkańców na cele publiczne, odwołania organu stanowiącego jednostki samorządu (rady gminy, rady powiatu, sejmiku wojewódzkiego oraz wójta, burmistrza, prezydenta miasta) przed upływem kadencji. Po drugie jest to referendum fakultatywne przeprowadzane w każdej innej sprawie ważnej dla społeczności lokalnej. Kolejnymi zagadnieniami tego rozdziału są mienie komunalne oraz Samorządowe Kolegium Odwoławcze.

W rozdziale czwartym „Prawo miejscowe i organy nadzoru” autor przypomina, iż prawo miejscowe to takie, które obowiązuje na części terytorium państwa i może być wydawane przez organy centralne lub terenowe. Prawo to stanowi źródło powszechnie obowiązujące na obszarze działania organów, które je wydały mianowicie na obszarze gminy, powiatu, województwa. Nie sposób w tym momencie pominąć organów nadzoru nad samorządem lokalnym.

Rozdział piąty „Wybory do samorządu lokalnego” stanowi najobszerniejszą część publikacji. W rozdziale tym szeroko omówione zostały prawa wyborcze zarówno czynne jak i bierne. Kolejną kwestią przedstawioną przez autora jest omówienie poszczególnych elementów wyborów. Są to: zarządzenie wyborów i ustalenie liczby radnych, obwody głosowania, spis wyborców, przebieg głosowania, ustalenie wyników głosowania, protesty wyborcze i ważność wyborów, komitety wyborcze, nadawanie numerów zarejestrowanym listom kandydatów, kampania wyborcza, finansowanie wyborów. Oddzielnie omówione zostały wybory do rad gmin, rad powiatów i sejmików województw. Przedstawiono przebieg wyborów uzupełniających.

Rozdział szósty i najkrótszy zarazem „Finanse samorządu lokalnego" dotyczy sposobu finansowania samorządu lokalnego. Wydatki samorządowe podzielone zostały na trzy grupy: wydatki bieżące, wydatki na obsługę długu oraz wydatki majątkowe. Omówione zostały również poszczególne etapy uchwalania budżetu. Autor przypomina, iż ustawa zasadnicza gwarantuje samodzielność finansową samorządu lokalnego.

Rozdział siódmy „Samorząd lokalny a standardy europejskie” odnosi się do Europejskich instytucji samorządowych, konwencji międzynaro- 
dowych. Autor odwołuje się do Europejskiej Karty Samorządu Terytorialnego. Jak przypomina jest ona efektem dążenia do ujednolicenia w skali ogólnoeuropejskiej rozwiązań samorządowych z zachowaniem specyfiki rozwiązań ustrojowych poszczególnych państw. Jak zauważa dalej autor bezpośrednią przyczyną prowadzenia prac nad EKST było dostrzeżenie w samorządzie terytorialnym, z jednej strony narzędzia, środka i pola działania zmierzającego do osiągnięcia celu w postaci ochrony praw i wolności jednostki, a z drugiej istniała obawa, że w przypadku przyznania zbyt dużego zakresu samodzielności samorządowi terytorialnemu przez ustawodawstwo wewnętrzne korzystanie z tych praw przez jednostkę będzie znacznie utrudnione lub ograniczone. W przepisach Karty zawarte są pewne zasady i postanowienia ogólne dotyczące funkcjonowania samorządu terytorialnego, do przyjęcia których zobowiązane są państwa członkowskie Rady Europy ${ }^{1}$. Należy przypomnieć, iż Polska ratyfikowała EKST w dniu 26 kwietnia $1993 \mathrm{r}$.

Rozdział ósmy „Systemy władzy lokalnej w Europie Zachodniej” to jak już widać z tytułu omówienie sposobu ukształtowania władzy lokalnej w państwach Europy Zachodniej. Autor odwołuje się w nim do przykładów takich państw jak: Francja, Wielka Brytania, Niemcy, Austria, Hiszpania, Belgia, Holandia, Szwajcaria. Struktura omówienia systemu władzy lokalnej oparta została w analogiczny sposób we wszystkich krajach.

Rozdział dziewiąty i ostatni zarazem „System władzy lokalnej w Europie Środkowo-Wschodniej" w którym autor nawiązał do przykładu państw takich jak: Bułgaria, Rumunia, Czechy, Słowacja, Węgry. Jego zdaniem reformy samorządowe w Europie Środkowo-Wschodniej stanowiły rezultat decentralizacji władzy państwowej. Samodzielne zaspokajanie potrzeb lokalnych przekazano danym wspólnotom. W omawianych państwach występuje zróżnicowany sposób kreacji organów wykonawczych gmin. Wybór bezpośredni organu wykonawczego wzmacnia jego pozycję

Rada Europy często mylona jest z instytucjami Unii Europejskiej: Radą Europejską i Radą Unii Europejskiej. Tymczasem Rada Europy powstała 5 maja 1949 r. w wyniku podpisania Traktatu Londyńskiego początkowo przez 10 państw. Jest to międzynarodowa organizacja rządowa skupiająca prawie wszystkie państwa Europy oraz kilka państw spoza tego kontynentu takich jak Armenia czy Azerbejdżan. Jej głównym celem jest „osiągnięcie większej jedności między jej członkami, aby chronić i wcielać w życie ideały i zasady stanowiące ich wspólne dziedzictwo oraz aby ułatwić ich postęp ekonomiczny i społeczny". Realizując tak określony cel organizacja ta zajmuje się przede wszystkim promocją i ochroną praw człowieka demokracji i współpracą państw członkowskich w dziedzinie kultury. 
w strukturze organów gminy. Inna sytuacja występuje w Czechach, gdzie starosta jest przewodniczącym wieloosobowego organu wykonawczego.

Reasumując należy stwierdzić, iż napisana przystępnym językiem książka Jacka Wojnickiego mimo drobnych niedociągnięć korektorskich (na str.76 zamiast samorząd wojewódzki widnieje dwa razy samorząd gminny) jest wartościową publikacją, która w zwięzły i logiczny sposób przedstawia istotę samorządu lokalnego w Polsce i Europie. Poza tym stanowi kompendium wiedzy o samorządzie terytorialnym zarówno dla osób posiadających wiedzę na omawiany temat, jak również dla tych, którzy dopiero uczą się zagadnień związanych z samorządem. 